\title{
Institutional implications of the rise of a debt-based monetary regime in Europe
}

\section{Losada Fraga, Fernando}

2017-05-25

Losada Fraga , F 2017 , ' Institutional implications of the rise of a debt-based monetary regime in Europe ' , European Law Journal , vol. 22 , no. 6 , pp. 822-837 . https://doi.org/10.1111/eulj.12223

http://hdl.handle.net/10138/308444

https://doi.org/10.1111/eulj.12223

cc_by_nc

acceptedVersion

Downloaded from Helda, University of Helsinki institutional repository.

This is an electronic reprint of the original article.

This reprint may differ from the original in pagination and typographic detail.

Please cite the original version. 
This is the peer reviewed version of the following article:

Fernando LOSADA, 'Institutional implications of the rise of a debt-based monetary regime in Europe', 22 (2016) European Law Journal, 822-837 which has been published in final form at https://doi.org/10.1111/eulj.12223.

This article may be used for non-commercial purposes in accordance with Wiley Terms and Conditions for Use of Self-Archived Versions. 


\title{
Institutional implications of the rise of a debt-based monetary regime in Europe
}

\author{
Fernando Losada *
}

This article deals with the institutional implications for the European Union resulting from debt relations. It suggests that despite original efforts to tame them, as a consequence of a series of events both in the international monetary order and the European integration process, power games lying behind debt relations have finally sprouted -with special virulence after the great recession. Although the causes have been brewing for a long time (in this regard the end of the monetary order established at Bretton Woods and the liberalisation of capital movements have been key factors), it is only in the post-economic crisis context that concrete examples of debt-based power games are observable in the institutional system. In hindsight, a line can actually be drawn tracing a transformation in the principle underlying EU constitutional law and its institutions: from promoting equality among its Member States to reflecting their (now persistent and increasingly divergent) economic power.

\section{I.- Introduction}

It is common knowledge that money is a means of exchange, a unit of value and a store of wealth. But as economic historians and sociologists have shown, monetary orders tend both to reflect power relations while being a major factor in shaping their transformation. In a nutshell, monetary orders are a key lever of power. ${ }^{1}$ This is so not only of national, but also international and cross-national monetary orders. Despite the implicit and sometimes explicit assumptions of most EU scholars, European integration is no exception to this rule.

Awareness of how debt shapes relations among EU states has increased since 2007, but confusion still abounds in terms of the dynamics of debt relations and their impact on the structural and substantive constitutional law of the European Union. This article focuses on the relationship between the international monetary order and European integration. In particular, it considers how as a result of a series of events on these two fronts debt relations and their associated underlying power asymmetries have finally come to explicitly pervade the institutional system of the European Union, originally inspired by the principle of formal equality between states but presently reflecting Member States' economic power. Two deeply interconnected dimensions, the politico-economic and the institutional, are therefore examined in parallel along the process of integration, although special attention is devoted to post-crisis institutional developments.

To a considerable extent, debt owed to creditors established in other states, regardless of it being public or private (what in economic terms is known as 'external debt'), determines relationships between states. ${ }^{2}$

\footnotetext{
* This research forms part of the European Bonds: The Moral Economy of Debt research project, funded by the University of Helsinki and the Academy of Finland.

1 M. de Cecco, Money and Empire. The International Gold Standard 1870-1914 (Blackwell, 1974); D. Graeber, Debt: The First 5000 years (Melville House, 2011).

2 For a longer-term historical account see K. Dyson, States, Debt, and Power: 'Saints' and 'Sinners' in European History and Integration (Oxford University Press, 2014), at 99-126; for a shorter-term $20^{\text {th }}$ century explanation see
} 
Thus, not only public debt, but also private debt is relevant, if only because the risk associated with private cross-border debt relations may end up involving states, as guarantors of last resort of debtor and creditor financial institutions. In these debt relationships the balance in the power game between creditor and debtor depends on the degree to which the given state keeps control over trade in goods and services, over capital movements, over the currency and over the terms of indebtedness.

In what follows, three different (even if deeply interrelated) types of external debt are distinguished: (1) debt stemming from commercial, non-financial cross-border activities; (2) debt resulting from cross-border financial flows; and (3) obligations between or among states (resulting from loans or reparations). Quite clearly, the first and the second type tend to be deeply intertwined in present practice. However, it is important to distinguish between them, if only because the power associated with external debt is heavily dependent on the extent to which states can effectively control and steer cross border capital movements and retain monetary sovereignty. Combining free movement in goods and services with controls on capital and coexisting national currencies, as was the case in the original European Communities, in the long run tends to level off the very same trade in goods and services. This is so because of the impact that a deficit or a surplus will have on the exchange rate of the national currency, and of the difficulty in perpetuating deficits or surpluses in the absence of freedom to provide loans across borders. Persistent trade deficits over many years are only possible if they come hand in hand with cross-border financial flows, thus creating long-term debt relationships. In addition, states may opt to seek external funding when issuing their sovereign bonds. As long as states retain control over the legal status of their bonds (issuing debt governed by national law) and over the issuance of money, an element of balance remains in relationships between creditors and debtors. Even so, creditors may require a state to renounce those elements as a condition for the issuance of credit. Finally, debts between states were characteristically the product of reparations, of military alliances, or of quasi-colonial relationships. The post-war Bretton Woods order envisaged a multilateral framework that aimed implicitly at rebalancing the position of creditors and debtors (as part of the transformation of the terms of international trade). However, in a very marked fashion since the seventies, international practice has resulted in the conditionality attached to official loans turning into a massive instrument to suspend the capacity of the debtor state for self-government. This article, while tracing the development and expansion of debt relations during European integration, will lead to the conclusion that a similar evolution has taken place in the European context.

\section{II.- The original treaties: a design neutralising debt relations}

During the first decades of integration, international monetary stability was guaranteed by the Bretton Woods system, according to which the dollar was directly convertible into gold while exchange rates between all other currencies were fixed, although revisable if required. ${ }^{3}$ The IMF was available to provide financial assistance in the event of economic shocks that could not be solved via exchange rate adjustment. ${ }^{4}$

In this context of exogenously guaranteed monetary stability, the specific design enshrined in the Treaty of Rome assumed that national economies would be open to competition and engage in the construction of a

K. Dyson, 'Norman's Lament: The Greek and Euro Area Crisis in Historical Perspective', (2010) 15 New Political Economy 597-608, at 600-603.

3 M. D. Bordo, 'The Bretton Woods International Monetary System: A Historical Overview', in M. D. Bordo and B. Eichengreen (eds.), A Retrospective on the Bretton Woods System: Lessons for International Monetary Reform (University of Chicago Press, 1993), 3-98, at 49.

4 Article V, Section 3, IMF Articles of Agreement. 
common market to result in liberalisation of the movement of goods and services, and which would lead to full political and economic union in the long run. Meanwhile, Member States retained competence over macroeconomic policies, albeit they were to be coordinated on a European scale, a task placed in the hands of what would become the ECOFIN, with the help, in terms of monetary policy, of a merely consultative Monetary Committee (Articles 3(g) and 105 EEC Treaty). Moreover, they were required to maintain their balance of payments in equilibrium and to promote confidence in their national currency (Article 104 EEC Treaty) so as to avoid currency fluctuations, which might artificially alter competitiveness within the common market.

In this framework, economic integration mainly referred to the free movement of goods and only current payments were allowed (Article 67 EEC Treaty). Both the European Payments Union and the Bretton Woods system were premised on the assumption that full liberalisation of capital flows undermined economic stability. In this regard liberalisation was a long-term task, to be decided only after institutional and substantive convergence allowed recreation at the European level of the socioeconomic and political conditions which ensured that free movement of capital was not an economically and politically disruptive force. ${ }^{5}$ Capital movements were accordingly supposed to be restricted and under strict scrutiny. ${ }^{6}$ If, despite all these safeguards, exceptional but severe difficulties in the balance of payments of some particular Member State should arise, the Treaty foresaw the means to ensure containment of crises and preservation of equality among Member States. States experiencing difficulties were to be assisted, if necessary by credits granted by the Communities (Articles 108 and 109 TEC); if those credits were not granted, they were at least allowed to activate 'safeguards', thus limiting (exceptionally and temporarily) the free movement of goods.

The EEC Treaty's main assumptions were thus rooted in the foundations of the Bretton Woods agreement: despite pooling together some competences, Member States retained the ability to autonomously design their most relevant policies -and among them, importantly, economic ones. Monetary stability, by guaranteeing a level playing field for all states, was a key factor in achieving this goal, turning exports into a key driver of economic growth. To that aim, cross-border payments (but not movements of capital) had to be possible. Potential imbalances were to be dealt with through loans, either by the IMF or the EEC, but in any case loans granted on the basis of compensating a systemic dysfunction rather than the misbehaviour of the assisted states, and thus not imposing hard conditionality on them.

This collaborative spirit, based on the resilience of nation-states despite being engaged in the European integration process, ${ }^{7}$ was reflected at the institutional level in the principle of equality between Member States. Consequently, the EEC Treaty established a series of mechanisms that deactivated economic-based power relations between them. For instance, during the transitional period decisions in the Council were to be adopted unanimously and therefore Member States were equally represented therein. Moreover,

5 In this period the scope of liberalization of capital flows was very limited. See First Council Directive for the implementation of Art. 67 EEC, OJ Special Edition, 1959-1962, 49; and Second Council Directive (63/21/EEC) adding to and amending the First Directive, OJ Special Edition, 1963-1964, 5.

6 The only exception in this regard was Germany, which liberalized capital movements in 1961. The ordo-liberal convictions of Ludwig Erhard, then Ministry of Economics and later Chancellor of the Federal Republic, conceived all political intervention over monetary policy as potentially leading to market distortions and ultimately to inefficiencies and instability. This applied as well to the external dimension of monetary policy, namely the exchange rate of the currency, so that Germany renounced effective determination of the Deutsche Mark exchange rate by liberalizing capital flows.

7 A. Milward, The European Rescue of the Nation-State (Routledge, 1992). 
although after the end of the transitional period the Treaties foresaw that some Council decisions were to be adopted by qualified majority instead of unanimously, due to the Luxemburg compromise they were only approved if no Member State rejected the proposal, thus de facto observing unanimity and the principle of equality between states. The role of the Council was accordingly central in the EU institutional system, as the forum reflecting Member States' equality. But the main flaw of this design, as would soon be proved, was that it was fundamentally dependent on the monetary stability provided by the Bretton Woods system.

\section{III.- The end of Bretton Woods: towards a new socio-economic model}

In 1971, urged by relentless inflation provoked by the escalation of the Vietnam War, US President Nixon unilaterally decided to cease the direct convertibility of the US dollar into gold. ${ }^{8}$ The immediate consequence was the collapse of the post-war international monetary order, furthered by the multiplication of turmoil all around the globe after the oil embargo by the OPEC countries and the subsequent economic recession. All these events represented extremely serious concerns for the EEC, since monetary instability and currency fluctuations had the potential not only to distort the common market but to jeopardize the smooth operation of the by then most successful achievement of European integration, namely the Common Agricultural Policy -based on a system of common price regimes.

In the light of these circumstances the Member States adopted safeguard measures allowing implementation of specific controls in the event that a significant amount of capital flows occurred, especially those directed towards third countries. ${ }^{9}$ But these safeguards could not counteract the expectation of potentially huge profits made from currency oscillations. Furthermore, demand for financial services allowing companies and investors to hedge the risks associated with the structural growth of monetary and economic uncertainty spiralled out of control. Hence, the structural strength of financial markets in the international monetary setting soon revived. ${ }^{10}$ In this context, divergences between the different economic policies implemented in the Member States became relevant beyond the mere rhetorical domain for the first time. Under the conditions guaranteed by the Bretton Woods monetary order, Keynesian policies, promoting demand-side stimulus and associated with the control of capital flows, succeeded in combining growth with welfare policies. However, after the demise of the direct convertibility of the US dollar into gold, stability-oriented economic policies proved more effective. In particular, financial markets approved them because low inflation and a stable exchange rate guaranteed the value of investments and assets in the medium and long term, minimizing the risk of losses.

Against that backdrop was established the European Monetary System (EMS), aiming at endogenously restoring monetary stability among the Members of the Community by means of containing currency fluctuations within certain limits. ${ }^{11}$ This implied the partial renunciation by Member States of their ability to determine the exchange rate of their currency, thereby curtailing the autonomy of their fiscal policies. The

8 In addition to those circumstantial reasons of domestic policy, Nixon's decision was the consequence of several structural distress factors affecting the post-war international monetary order. See P. M. Garber, 'The Collapse of the Bretton Woods Fixed Exchange Rate System', in Bordo and Eichengreen (eds.), n. 3, 461-485. Council Directive (72/156/EEC) 'on regulating international capital flows and neutralizing their undesirable effects on domestic liquidity', OJ L 91, 18.4.1972, 296-297.

10 E. Helleiner, States and the Reemergence of Global Finance: From Bretton Woods to the 1990s (Cornell University Press, 1994), at 111-121.

11 E. Mourlon-Druol, A Europe Made of Money: The Emergence of the European Monetary System (Cornell University Press, 2012). 
Deutsche Mark soon became the de facto anchor currency of the system because the re-emerging financial markets favoured the German policy of a consistent fight against inflation, whereas Italy, France and Ireland experienced major balance of payments disequilibria. ${ }^{12}$ In the long run, the performance of the German and Dutch stability-oriented economies compared to the structural problems of the latter economies led to the unravelling of the Keynesian consensus on active macroeconomic policy playing a key role in stabilising the economy. Price stability gained support instead as the appropriate economic policy among economists and central bankers in Exchequers and Ministries of Finance. Thus was born what would be an extremely influential epistemic community of European central bankers. ${ }^{13}$

The role of the international monetary institutions in the spread and general acceptance of economic policies based on price stability should not be neglected, though. As a consequence of the breakdown of the Bretton Woods agreement the tasks and functions of the IMF and the World Bank were revised. ${ }^{14}$ Instead of guaranteeing the convertibility of currencies in a system with exchange rates tied to gold, they were now to monitor national balances of payments in a regime of flexible exchange rates, making detailed policy proposals with economic stability in mind. ${ }^{15}$ But, on top of that, the financial assistance they continued to provide had to be conditioned for the first time on implementation of detailed policy programmes redressing balance of payments disequilibria and limiting external debt. ${ }^{16}$ In this regard price stability guaranteed suitable conditions for achieving economic stability in the long run. Assistance was thus no longer based on the correction of malfunctions inherent to the international monetary order but on the rectification of policies resulting from the misbehaviour of national political actors that have now to conduct economic policies according to the 'good governance' paradigm -a set of policies considered right that would lead to national economic stability in the current monetary regime. ${ }^{17}$ Therefore, against the original intention of the Bretton Woods agreements, power relations were reintroduced in the international monetary order through provision of conditional loans with increasingly intrusive provisions.

The establishment of the EMS shielded Member States (although not completely) from these power relations. A growing respect among European politicians for the autonomy of monetary policy and its institutional corollary, central bank independence, stemmed from the Bundesbank's actual performance. The result was the gradual disengagement of central banks from Treasury departments. Member States thereby transferred to monetary authorities their ability to decide on the purchase of sovereign bonds, now dependent on monetary instead of fiscal policy needs. Liberalisation of capital flows appeared then as an alternative source for public debt allocation, thus alleviating budget difficulties consequent on the increasing gap between national revenue and expenses. ${ }^{18}$ The unilateral liberalisation of capital movements adopted by the United Kingdom in October $1979,{ }^{19}$ followed by a similar move by the Netherlands the next

12 On the division of Member States into two groups regarding their performance under the Werner Plan see D. Gros and N. Thygesen, European Monetary Integration: From the European Monetary System to European Monetary Union (Longman, 1992) at 35.

13 A. Verdun, 'The Role of the Delors Committee in the Creation of EMU: An Epistemic Community?', (1999) 6 Journal of European Public Policy, 308-328. Cf. E. B. Kapstein, 'Between Power and Purpose: Central Bankers and the Politics of Regulatory Convergence', (1992) 42 International Organization 265-287.

14 Second Amendment of the Articles of IMF Agreement (1978).

15 M. Garritsen de Vries, The International Monetary Fund, 1972-1978: Cooperation on Trial (Vol. II): Narrative and Analysis (IMF, 1985) at 756.

16 M. Garritsen de Vries, The International Monetary Fund, 1972-1978: Cooperation on Trial (Vol. I): Narrative and Analysis (IMF, 1985) at 487-489.

17 N. Woods, The Globalizers: The IMF, the World Bank, and Their Borrowers (Cornell University Press, 2006) at 48.

18 J. O'Connor, The Fiscal Crisis of the State (St. Martin's Press, 1973) at Chapter 7.

19 Helleiner, n. 10, at 150-151. 
year, ${ }^{20}$ opened the door to a change of debt relations in Europe: where initially public debt was mainly in the hands of national citizens and institutions, now foreign capital was holding those bonds to a greater extent than ever. Public debt thus became a source of external debt, linking Member States to private actors, mainly financial institutions, from other countries. The move towards a new regime of monetary policy detached from governmental control and accompanied by the acceptance of capital movements, with all the implications here described, was finally confirmed by the policy U-turn taken by the French Socialist government in $1983,{ }^{21}$ leading to Bérégovoy's franc fort policy. ${ }^{22}$ Therefore, by the time EMU was negotiated in the late 1980s, all actors, independently of their ideological background, not only agreed to liberalize capital movements ${ }^{23}$ but tended to be persuaded of the benefits of price stability, ${ }^{24}$ which became the core objective of monetary union.

At this point the institutional system of the Communities was nevertheless safe from reflecting tensions resulting directly from debt relations, but this did not prevent them from permeating into the political arena. In this regard, the decisive role played by the Committee of Central Bank governors in the design of Economic and Monetary Union (EMU) in the $1980 \mathrm{~s}^{25}$ constituted a first avenue for debt-based power relations to gain influence in the $\mathrm{EU}$ institutional system. Less obviously but also rather decisively, the creation of the European Council, closely related to the monetary and economic crises of the early 1970s, was a major vehicle for institutional drift away from the principle of equality among states. ${ }^{26}$ Although the European Council gathers all heads of state and government as Masters of the Treaties and thus formally recognises equality among them (even more so since the basic features of the institution were included in the Treaties and its functions detailed therein), economic relations between states may have de facto affected political discussions. Indeed, since its inception the European Council has fostered asymmetric relations among states, not least on the basis of their different economic and financial might.

\section{IV.- The Treaty of Maastricht: laying the foundations of a new debt regime}

The Treaty of Maastricht designed not only the path towards but also the constitutional framework of EMU, which resulted in a rearrangement of the whole set of debt relations between EU Member States and between them and third countries. Unlike the original treaties, drafted in accordance with the context of monetary stability provided by the Bretton Woods agreement, the provisions designing EMU in the Treaty of Maastricht were not aimed at neutralising debt relations between Member States, but instead focused on the actual establishment and operation of a common currency. In terms of international debt relations, that was said to allow regaining of control over some of the key elements of debt. For instance, by making

20 The Benelux countries fully liberalized capital movements between themselves.

21 On the reasons for this change, see Helleiner, n. 10, at 140-145; V. A. Schmidt, From State to Market? The Transformation of French Business and Government (Cambridge University Press, 1996) at 94-130; R. Abdelal, Capital Rules: The Construction of Global Finance (Harvard University Press, 2007) at 28-65; and M. Loriaux, France after Hegemony. International Change and Financial Reform (Cornell University Press, 1991) at Chapter 8.

22 This was bolstered by French consent to adoption of a Council Directive (86/566/EEC) amending the First Directive of 11 May 1960 for the implementation of Article 67 of the Treaty, OJ L 332, 26.11.1986, 22-28.

23 Council Directive (88/361/EEC) for the implementation of Article 67 of the Treaty, OJ L 178, 8.7.1988, 5-18.

24 The EEC Monetary Committee played a major role in spreading the merits of stability-oriented policies. See Dyson, States, Debt, and Power..., n. 2, at 605.

$25 \mathrm{H}$. James, Making the European Monetary Union: The Role of the Committee of the Central Bank Governors and the Origins of the European Central Bank (Belknap Press, 2012).

26 On the notion of drift in institutional change studies see W. Streeck and K. Thelen, 'Introduction: Institutional Change in Advanced Political Economies', in W. Streeck and K. Thelen (eds.), Beyond Continuity: Institutional Change in Advanced Political Economies (Oxford University Press, 2005), 1-39, at 24-26. 
the euro a currency of reference the EU could gain independence from other currencies, the US dollar in particular, as de Gaulle had wished as long ago as the $1960 \mathrm{~s}^{27}$ But the political narrative of the euro as a common goal overshadowed the internal debt relations that the concrete path chosen to achieve that aim would eventually entail. Moreover, because of the specifics of the interests involved in negotiating the Maastricht Treaty, a debt regime with potentially destructive consequences was established.

As is well known, EMU is founded on an unprecedented asymmetry: Eurozone Member States share a common monetary policy coexisting with various national economic policies. The institutional design of EMU revolves around an independent central bank (the European Central Bank, ECB) with exclusive competence over monetary issues, leaving Member States responsibility over their national economic policies. Importantly, since Germany accepted introduction of a common currency before EMU was an optimal currency area ${ }^{28}$ (or at least a sufficiently integrated one), fiscal transfers between states or via Central Bank financing had to be ruled out in order to avoid adjustments at the expense of taxpayers from other Member States. Hence, they cannot assume financial responsibilities from any other Member State (the 'no bailout' provision, Article 125 TFEU). ${ }^{29}$ These transfers may also occur indirectly, via central bank financial support, but the latter is equally forbidden in order to guarantee monetary stability (Article 123 TFEU). Consequently, by conferring monetary policy competences on the extremely independent ECB, Member States renounced the tools of currency devaluation and money creation to face balance of payments and sovereign bond repayment crises. Instead of that, the design of EMU forced them to rely on financial markets for financing. According to this logic, the markets would assess economic performance of each Member State and establish a specific risk premium when those states borrow money, allegedly contributing to discipline those more reluctant to adapt their economic policy to the requirements of EMU. ${ }^{30}$ A key element in this design is a broadening of the scope of free movement of capital, now allowing flows both to and from third countries ${ }^{31}$ and therefore strengthening the structural influence of financial markets. A direct consequence of the liberalisation erga omnes of capital flows was the increase of tax competition between Member States, which in order to attract mobile capital are forced either to establish a more regressive tax structure or to lose government revenues, ${ }^{32}$ thus aggravating their difficulties in balancing the accounts. Fiscal consolidation thus became a structural feature of EMU, likewise furthering the soundness of (national) economic policies required for price stability. Fiscal consolidation is therefore considered an instrumental objective of EMU and, as such, is promoted through institutional incentives: with their budgetary options constrained by the Stability and Growth Pact (SGP) and, especially, by subjecting their financing to capital markets, Member States have strong reasons to conduct responsible policies. In this regard, resort in the management of economic policies to a new set of arrangements

27 Ch. de Gaulle, Discours et Messages (Vol. IV): Pour l'effort (1962-1965), (Plon, 1970) at 330-334.

28 R. A. Mundell, 'A theory of optimum currency areas', (1961) 51 American Economic Review 657-665.

29 Accordingly, balance of payments assistance mechanisms (currently Articles 143 and 144 TFEU) are not applicable to Eurozone states.

30 O. Issing, The Birth of the Euro (Cambridge University Press, 2008), at 18; H. Enderlein, 'Towards an Ever Closer Economic and Monetary Union?', in M. Dawson, H. Enderlein and Ch. Joerges (eds.), Beyond the Crisis: The Governance of Europe's Economic, Political, and Legal Transformation (Oxford University Press, 2015), 13-23, at 19-20.

31 The Treaty of Maastricht amended the original treaties on free movement of capital (currently Articles 63 to 66 TFEU) so as to establish freedom erga omnes with a drafting sufficiently clear, precise and unconditional as to confer the provision direct effect.

32 The effects of liberalization of capital flows in the international domain are of a greater scale because they enhance tax competition between developed and developing countries, whose differences polarise their options: the former must reduce progressivity while the latter must lose revenue. See P. Dietsch, Catching Capital: The Ethics of Tax Competition (Oxford University Press, 2015) at 48-51. 
comprised under the 'governance' narrative (including benchmarking and peer reviewing) rather than to law, allowed new power-based relations between Member States to infiltrate the institutional setting.

Evolution in this regard was gradual. With the Single European Act (1986) a move to voting rights proportional to Member States' population followed a resolution to achieve the single market by the end of 1992. Qualified majority voting became standard in matters conducive to that objective and, once achieved, in an increasing number of areas thanks to the Treaty of Maastricht. However, this did not lead so much to actual decision-making by qualified majority voting as to both the Commission and the Council (and the European Parliament as it acquired legislative powers) to work under the shadow of the possibility of decisions being taken by a qualified majority. ${ }^{33}$ Apart from this first relevant step moving away from the principle of equality among states, the new institutions set up to flesh out EMU were all informed by it. This was the case of the Eurogroup, an ad hoc institutional solution for the event that not all Member States of the Union became Members of the Eurozone, leading in practice to the emergence of a separate composition of the ECOFIN where only Eurozone Chancellors of the Exchequer and/or Ministers of Finance meet. This body lacks formal competence to adopt decisions, and thus functioned as a forum where issues of common concern were discussed before the actual ECOFIN meeting took place. It has been described as a genuinely deliberative body, ${ }^{34}$ or what is the same, as a body where political conflict between Member States would be downscaled. ${ }^{35}$ However, the fact that it was designed to be informal, in particular after the entry into force of the Treaty of Lisbon, ${ }^{36}$ makes it especially apt for power-based relations, because the lack of formal or procedural constraints gives free leeway to powerful states, whatever the source of that power is, to express their interests and ultimately to impose their views.

A similar dual structure emerged in terms of monetary policy: together with the ECB, central banks from all Member States formed the European System of Central Banks, while the Eurosystem grouped the ECB with Eurozone central banks only. The difference with its counterpart on economic policy coordination is that the Eurosystem actually adopts decisions in its field of competence (monetary policy). More specifically, the decision-making body of the Eurosystem, the Governing Council, is composed of the six members of the Executive Board (elected between all Member States) and the governors of national central banks. Albeit this seems to alter the principle of equality among states, the technical and thus non-political character of the body allows it to work under a presumption of consensus -allegedly, members of the epistemic community will always agree on what is the correct decision in a given context. ${ }^{37}$ In other words, as long as the issues discussed in the Governing Council are of technical character, political discussions are discarded.

Apart from guaranteeing the independence and well-functioning of the $E C B$, the main concern of the institutional framework designed in the Maastricht Treaty was to address the main structural weakness of EMU, namely that it relied on the will of national governments to conduct their economic policies in line

33 J. H. H. Weiler, 'The Transformation of Europe', (1991) 100 The Yale Law Journal 2403-2483, at 2461.

34 U. Puetter, The Eurogroup: How a Secretive Circle of Finance Ministers Shape European Economic Governance (Manchester University Press, 2006), at Chapter 7.

35 Ch. J. Bickerton, European Integration: From Nation-States to Member States (Oxford University Press, 2012), at 35.

36 Article 1 of Protocol (No 14) to the Treaty of Lisbon, on the Eurogroup, reinforced that ability by stating that "[t]he Ministers of the Member States whose currency is the euro shall meet informally" (emphasis added). Hence, the informal character of the meetings has been formally established.

37 P. M. Haas, 'Introduction: Epistemic Communities and International Policy Coordination', (1992) 42 International Organization 1-35, at 3. 
with common monetary policy in a constellation of interests promoting freeriding. ${ }^{38}$ However, far from contributing to the much aspired overall stability of EMU, the measures dealing with these misaligned incentives contained several hidden flaws that in the long run led to changes in the structure of economic relations between Member States. First, the limitation of national macroeconomic policies through the SGP was supposed to work similarly to negative integration in the internal market, but since EMU was based on governance arrangements rather than law, ${ }^{39}$ the control the CJEU could make was merely procedural. ${ }^{40}$ Sanctioning of deviant behaviour depended on the discretion of the Council, which lacked political incentives when the country concerned was among the prominent economies. ${ }^{41}$ Second, once the common currency was established the effectiveness of markets in disciplining Member States diminished because the risk of devaluation disappeared. From then on, differences between sovereign bonds denominated in euros depended on their liquidity, with interest rate spreads remaining relatively low. It is true that a solvency risk remained, but the case of sovereign bankruptcy was considered a remote possibility. ${ }^{42}$ And third, focus on the development of national economic policies distracted attention from other macroeconomic indicators, in particular from massive capital flows from the centre to the periphery that, following the establishment of fixed parity of currencies and thus the elimination of all risks associated with exchange rates, led to substantial imbalances in their respective balances of payments. ${ }^{43}$ Ultimately the severe transnational implications of these capital flows directly affected the coming decision to force Greece to accept financial assistance instead of allowing it to default. ${ }^{44}$

In sum, EMU created a common currency at the price of leaving its members without the ability to decide on their exchange rate, with no influence on decisions about the amount of money circulating in the economy (now a matter in the hands of the ECB), and with no mechanism of financial assistance should difficulties arise. But not only that, because through the complete liberalisation of capital movements the new regime gave financial markets structural power over its members. Neglect of the risks of imbalance represented by internal flows from the centre to the periphery, initially interpreted as a sign of convergence between EMU members, increased the potentially destructive effects of debt relations between Member States, a seed that finally germinated during the economic crisis.

38 A. Weale, 'Political Legitimacy, Credible Commitment, and Euro Governance', in Dawson, Enderlein and Joerges (eds.), n. 30, 185-202, at $187 \mathrm{ff}$.

39 The proponents of the 'new intergovernmentalism' have identified institutional reliance on consensus among intergovernmental institutions as the defining feature of post-Maastricht integration. See Bickerton, n. 35; U. Puetter, The European Council and the Council: New Intergovernmentalism and Institutional Change (Oxford University Press, 2014); Ch. J. Bickerton, D. Hodson and U. Puetter, 'The New Intergovernmentalism: European Integration in the Post-Maastricht Era', (2015) 53 Journal of Common Market Studies 703-722; Ch. J. Bickerton, D. Hodson and U. Puetter (eds.), The New Intergovernmentalism: States and Supranational Actors in the PostMaastricht Era (Oxford University Press, 2015).

40 C-27/04, Commission vs Council, EU:C:2004:436.

41 Pecuniary sanctions would most likely worsen the pledge of sanctioned countries, triggering a deflationary cycle likely to end up hitting all Eurozone states. This may well have weighed heavily against sanctions, as surely did the expectation of reciprocal treatment if leniency was tolerated.

42 Issing, n. 30, at 18.

43 C. Lapavitsas, Profiting Without Producing: How Finance Exploits Us All (Verso, 2013) at 292-293. The impact of extensive wage moderation in Germany in the deepening of those asymmetries has been stressed by Lapavitsas himself (at 291-292) and J. Bibow, 'On the Franco-German Euro Contradiction and Ultimate Euro Battleground', (2013) 32 Contributions to Political Economy, 127-149, at 139.

44 F. W. Scharpf, 'Political Legitimacy in a Non-Optimal Currency Area', in O. Cramme and S. B. Hobolt (eds.), Democratic Politics in a European Union Under Stress (Oxford University Press, 2015) 19-47, at 25; F. Steinberg and M. Vermeiren, 'Germany's Institutional Power and the EMU Regime after the Crisis: Towards a Germanized Euro Area?', (2016) 54 Journal of Common Market Studies 388-407, at 390. 


\section{V.- The great recession: the resurgence of debt relations within the European Union}

A new regime of debt relations took shape in the general context of the economic framework set up in the Maastricht Treaty, but resulting from a highly concrete decision that triggered a set of changes unfolding and spreading through different areas, and of such a foundational character that they have been labelled as 'constitutional mutations'. ${ }^{45}$ A combination of several causes, from continued excessive deficits and questionable statistical data ${ }^{46}$ to sustained tax evasion and, crucially, a pronounced current account deficit following massive capital inflows from other Member States, put Greece in a critical situation. With the gap between reality and figures on public deficit being wider than expected, and without the possibility of autonomously devaluing its currency or increasing the amount of money in circulation, doubts arose about Greece's ability to service its debt. Moreover, in the context of far-reaching financial turbulence triggered by the US sub-prime crisis, the markets radically changed their assessment and massively increased the risk premium on Greek bonds, thus blocking all its refinancing operations. The European Council was suddenly faced with the dilemma of either allowing the default of a Eurozone member, thus accepting that creditors (mostly European financial institutions) would assume their share of the losses and that the credibility and stability of the Euro in the international scene would be put into question, or granting financial aid to a bigger extent than in previous, non-Eurozone cases, ${ }^{47}$ against the rationale underpinning the constitutional design of EMU (and especially the 'no bailout' clause enshrined in Article 125 TFEU). It is common knowledge that the European Council opted for the latter. This decision triggered the unfolding of the debt crisis, forcing Eurozone Member States to borrow money from other Eurozone Member States, thus engaging in state-to-state debt relations. The apparent unconstitutionality of lending was said to be avoided by means of subjecting financial assistance to strict conditionality. ${ }^{48}$ The latter is what defines current debt relations in Europe: borrower Member States are forced to sign a Memorandum of Understanding (MoU) by which they commit to implementing a whole range of political and economic measures as consideration for the financial support necessary to overcome the fiscal crisis. These new debt relations are thus an expression of power, reflected in the conditions attached to MoUs (a short and medium term programme of economic and political reforms) and of the procedure according to which successive tranches of financial aid are actually paid (indeed, only after confirmation of compliance with conditions attached to the previous tranche, set by the creditors themselves).

Combining the principle of national financial responsibility with the impossibility of default (affirmed against the letter of the law) implied that countries in financial need inevitably had to ask for financial assistance. As mentioned, this had to be subjected to strict conditionality, in order not to be considered a

45 A. J. Menéndez, 'La mutación constitucional de la Unión Europea', (2012) 96 Revista Española de Derecho Constitucional 41-98; and 'Editorial: A European Union in constitutional mutation?', (2014) 20 European Law Journal 127-141; K. Tuori and K. Tuori, The Eurozone Crisis: A Constitutional Analisys (Cambridge University Press, 2014), at Part II; K. Tuori, European Constitutionalism (Cambridge University Press, 2015) at Chapter 6.

46 However, it has been claimed that a series of statistical decisions, of which Eurostat was not ignorant, "resulted in the overestimation of the [Greek] deficit figure for 2009 between 6 and 8\% of GDP (and a 28 bn euro increase in the stock of Hellenic sovereign debt)". See I. Bantekas and R. Vivien, 'The Odiousness of Greek debt', (2016) 22 European Law Journal, 539-565, at 559.

47 Hungary, Latvia and Romania benefited from the application of the programme assisting non-Euro Member States experiencing difficulties in their balance of payments, established according to Article 143 TFEU by Council Regulation (EC) 332/2002, of 18 February 2002, establishing a facility providing medium-term financial assistance for Member States' balance of payments (OJ L 53, of 23.02.2002, p. 1-3).

48 This reasoning was upheld by the CJEU in its judgment in C-370/12, Pringle, EU:C:2012:756, paragraph 143. See also A. de Gregorio Merino, 'Legal developments in the Economic and Monetary Union during the debt crisis: the mechanisms of financial assistance', (2012) 49 Common Market Law Review 1613-1646, at 1627. 
fiscal transfer between Member States. ${ }^{49}$ Furthermore, it had to be accompanied by intensified monitoring of national economic policies from the supranational level, in order to remove the wrong incentives that institutionalisation of the different mechanisms of financial assistance ${ }^{50}$ entailed for national financial responsibility and the proper conduct of economic policies. This was achieved through an increase at the supranational level of monitoring, intervention and sanctioning powers over national economic policies, aptly named 'reinforced economic governance'. The consequence of this new regime is a radical change in how national economies are supposed to converge. Instead of resorting to their coordination, they are now disciplined through a plethora of measures: increased supervision over, and if necessary correction of, Member States' budgetary plans; reinforced monitoring procedures for macroeconomic indicators (balance of payments included); tightening of budgetary constraints (SGP); increase in the Commission's investigative powers, to the point of allowing on-site inspections; or semi-automatic imposition of pecuniary sanctions in cases of excessive deficit, to name but a few. Ultimately, limitations on national budgets are transferred to other (mainly social) policy areas in the form of required expenditure cuts in order to achieve fiscal consolidation.

The Greek financial position in 2010 highlighted that the solvency risk of Member States was not nonexistent but hidden in the EMU institutional setting, especially if they were to assume the debt of private institutions as if it was public debt. As soon as this was evident and financial difficulties spread, the continuation of the euro was at stake. The existential need to guarantee and safeguard the viability of the common currency led to a reinterpretation of the main (legal) principles of EMU, with financial stability replacing price stability as the cornerstone of the system..$^{51}$ Importantly, as shown by the Greek episode, this had as an additional consequence the first clear discrepancy between the international monetary order, concerned about sustainability of external debts, and European institutions, for whom sustainability of Greek debt was subjected to the stability of the Euro area. In other words, conditionality in EMU is not related to the sustainability of national debt but to the stability of the euro. Accordingly, it has no limits regarding the scope and breadth of policy measures required, which can easily be perceived as punitive by the affected states.

State-to-state debt dynamics in the context of EMU played a key role in triggering a constitutional mutation that extends to the institutional structure of the Union. The corollary is that in all new institutions equality among states has been replaced by the allocation of votes according to states' (economic) power. It could be argued that this is not the case with one of the main institutional innovations resulting from the crisis, the Eurosummit, a reduced version of the European Council where only Eurozone heads of state and government sit. However, the deeply asymmetrical relationship between creditors and debtors has unleashed a new dynamic according to which states, instead of operating under the presumption of

49 This implies that, contrary to what happened with private creditors, debt cuts or debt reliefs detrimental to the finances of creditor Member States or European institutions are to be considered in breach of EU law. See A. Steinbach, 'The "haircut" of public creditors under EU law', (2016) 12 European Constitutional Law Review 223239.

Currently composed of the secondary-law based European Financial Stabilisation Mechanism (Council Regulation (EU) 407/2010, OJ L 118, of 12.5.2010, 1-4, as amended by Council Regulation (EU) 2015/1360, OJ L 210, of 7.8.2015, 1-2) and the intergovernmental European Stability Mechanism (Treaty updated after Lithuania's accession), which was the successor to the Luxembourg-based European Financial Stability Facility.

51 In the words of the CJEU: "Compliance with such discipline contributes at Union level to the attainment of a higher objective, namely maintaining the financial stability of the monetary union". C-370/12, Pringle, EU:C:2012:756, paragraph 135. 
consensus, have started to operate under the presumption of conflict. ${ }^{52}$ Hence, the grammar of deliberation has been replaced by the grammar of power, and informal institutions and gatherings where decisionmaking is not regulated, such as the Eurosummit or the Eurogroup, have been easily pervaded by this new dynamic. Consequently, the interests of creditor and debtor states result in open conflicts, each position being straightforwardly identifiable with concrete heads of state or government at the Eurosummit or with ministers of economy and finance in the Eurogroup. The struggle between creditors and debtors is on the way to being transferred to the institutional system and, therefore, institutionalised.

Paradigmatic illustration of this conflictual dynamic can be found in the revamped constitutional structure of economic policy, the so-called 'reinforced economic governance'. With a view to ensuring fiscal discipline, it promotes the semi-automatic adoption of all sanctions proposed by the Commission. This was enabled through new, ad hoc voting rules deeming such a proposal to be adopted if the Council does not reject it by a qualified majority. A blocking minority can thus impede rejection by the Council or, reversing the terms, a minority can adopt those sanctions. ${ }^{53}$ These voting rules clearly benefit the interest of creditors, who are likely to gather the required number of votes. Whether the new rules will actually result in fiscal discipline being imposed by sanctions remains to be seen. Certainly an element of arbitrariness resulting from the need to assess whether the measures will actually help or undermine the fiscal position of the affected Member State seems to have informed the first decisions taken under the new rules. ${ }^{54}$

With regard to the permanent fund for financial assistance, the intergovernmental European Stability Mechanism (ESM), this has not escaped power conflict dynamics either. Not only because on its Board of Governors sit the Ministers of Finance of the Eurozone, thus replicating the composition and potentially the conflict dynamics of the Eurogroup, but also because voting rights therein are allocated according to the capital subscribed by each ESM member. This may in itself be regarded as the institutionalisation of economic power relations, but the asymmetries go well beyond that. Although all relevant decisions are to

52 Bickerton, n. 35, at 33.

53 This is the decision-making procedure applicable to most of the decisions regarding the excessive deficit procedure and the macroeconomic imbalance procedure, as established in the so-called Six-pack and Two-pack. For the former see Regulation (EU) No 1175/2011 'amending Council Regulation (EC) No 1466/97 on the strengthening of the surveillance of budgetary positions and the surveillance and coordination of economic policies', OJ L 306, of 23.11.2011, 12-24; Regulation (EU) No 1177/2011 'amending Regulation (EC) No 1467/97 on speeding up and clarifying the implementation of the excessive deficit procedure', OJ L 306, 23.11.2011, 33-40; Regulation (EU) No $1173 / 2011$ 'on the effective enforcement of budgetary surveillance in the euro area', OJ L 306, 23.11.2011, 1-7; Directive 2011/85/EU 'on requirements for budgetary frameworks of the Member States', OJ L 306, 23.11.2011, 41-47; Regulation (EU) No 1176/2011 'on the prevention and correction of macroeconomic imbalances', OJ L 306, 23.11.2011, 25-32; and Regulation (EU) No 1174/2011 'on enforcement measures to correct excessive macroeconomic imbalances in the euro area', OJ L 306, 23.11.2011, 8-11. For the Two-pack see Regulation (EU) No $472 / 2013$ 'on the strengthening of economic and budgetary surveillance of Member States in the euro area experiencing or threatened with serious difficulties with respect to their financial stability', OJ L 140, 27.5.2013, 110 and Regulation (EU) No 473/2013 'on common provisions for monitoring and assessing draft budgetary plans and ensuring the correction of excessive deficit of the Member States in the euro area', OJ L 140, 27.5.2013, 1123. Qualified minority voting is further entrenched by Article 7 of the Treaty on Stability, Coordination and Governance in the Economic and Monetary Union, by which Member States commit to always follow the proposal by the Commission, otherwise being obliged to give public explanations. See R. Palmstorfer, 'The Reverse Majority Voting under the 'Six Pack': A Bad Turn for the Union?', (2014) 20 European Law Journal 186-203.

54 Despite the original intention of such intensive legislative activity, political incentives to postpone or reject sanctions have not been avoided but merely transferred from the Council to the Commission, as is evident from disputes aired by the media regarding imposition of sanctions on Spain and Portugal during 2016. Announcement of sanctions was postponed on several occasions, being finally held in abeyance. This seems to suggest that the effective disciplining measure is the threat of economic sanctions rather than sanctions themselves. 
be adopted by unanimity, there is a fundamental exception: a qualified majority of $85 \%$ of votes cast suffices if the Commission and the ECB consider that the financial stability of the whole euro area is at stake. ${ }^{55}$ As a result, the Member States with the biggest economies get a right to veto which others simply do not have. ${ }^{56}$ Finally, the ESM is a creature of international law, not of EU law. Consequently, it has its own by-laws, and even a court adjudicating on civil service matters regarding its own employees, although it is compelled to comply with EU law and the case law of the Court of Justice. This results in a serious risk of the ESM becoming the administrative arm of the creditor-dominated Eurogroup in matters pertaining to financial assistance.

The internal dynamics of already established institutions have also changed in ways that favour creditors' interests. This is clearly the case of the ECB and the voting rules in force since EMU became a 19-member club. According to the rotating voting system in force, state influence depends on capital subscribed (5/6) and the weight of the financial sector (1/6) of each Eurozone state. In practice, governors from the five largest Eurozone economies (Germany, France, Italy, Spain and the Netherlands) vote four out of five times, while those from smaller economies vote eleven out of fourteen times. Inequality among states has been institutionalised, again reflecting (economic) power relations. ${ }^{57}$ However, precisely against the will of creditor countries, the ECB itself has become a creditor by adopting unorthodox monetary policy measures that have led to the acquisition of sizeable amounts of sovereign bonds, as well as by playing a key role in the so-called troika, monitoring implementation of MoUs in those states that have received financial assistance. ${ }^{58}$ What this entails in constitutional terms is perhaps best reflected in the letters addressed by the then ECB governor, Mr. Trichet, first to the Irish government, then to the Italian and Spanish governments, making rather extensive and significant requests in terms of national economic, fiscal and social policies. The constitutionalisation of the so-called golden fiscal rule, at least in Spain (plus the "absolute priority" of debt repayment over any other public expense), ${ }^{59}$ seems to be related to this epistolary relation. ${ }^{60}$ On top of that, the politicization of the ECB became manifest in the resignation of its chief economist, Jürgen Stark, motivated by his disagreement with the bond-buying programmes referred to above. Similar criticism of the ECB's unorthodox monetary policy comes frequently from the German financial and monetary authorities. ${ }^{61}$ Whatever assessment one makes of these claims, it is clear that the

55 Article 4.4 ESM Treaty.

56 F. Fabbrini, 'States' Equality v States's Power: the Euro-crisis, Inter-state Relations and the Paradox of Domination' (2015) 17 Cambridge Yearbook of European Legal Studies 3-35, at 18. In a similar vein, Article 48 ESM Treaty subjects entry into force of the Treaty to ratification by states which have subscribed in total at least $90 \%$ of the initial capital of the ESM, thus de facto entitling some of them to a veto power on the matter.

57 The difference in the voting rate of governors of Eurozone Central Banks is currently negligible, but will grow as (and if) the Eurozone further enlarges. In the event of becoming a 22-member club, governors will be divided into three groups. In a Eurozone of 25 Members governors of the first group will vote four out of five times, those in the second group eight out of thirteen times, and those in the third merely three out of seven times.

K. Tuori, 'From Expert to Politician and Stakeholder? Constitutional Drift in the Role of the ECB' in J. E. Fossum and A. J. Menéndez (eds.), The European Union in Crises or the European Union as Crises? (ARENA, 2014) 491-525.

59 Article 135.3 Spanish Constitution, as amended in 2010.

60 See the correspondence between Mr Trichet and the Irish Minister of Finance (http://tinyurl.com/kun4x58) and the letter from Mr. Trichet to Mr. Zapatero (http://tinyurl.com/qx3snmx). Links last checked on 2 March 2017.

61 As to the last example, German Minister of Finance, Wolfgang Schäuble's public statements establishing a causal relation between the low interest rate level in the Eurozone and the increase of populist movements. 
actual constitutional role of the ECB has been deeply distorted, to the point that it can be doubted what remains of its independence beyond the formalities. ${ }^{62}$

In sum, post-crisis debt relations have unleashed a conflictual dynamic that has spread throughout the Union, transforming its institutional structures according to a creditor mind-set. This is clearly expressed by the turn in the inspiring principles underpinning the institutional system. Not only do new institutions respond to the (economic) power of the Member States, but even those well-established before the crisis, despite being legally informed by the principle of equality among members, have been pervaded by the current conflicting dynamics. In other words, creditors' interests have now been institutionalised, to the point that dissenting opinions tend to be characterised as dangerous, because they may discredit the Union and thus undermine the financial stability of the Eurozone as a whole. The (apparent) strengthening of fiscal discipline has come at the price of undermining the legitimacy of the Eurozone.

\section{VI.- Conclusions}

The evolution here described traces the changes in European integration resulting from debt relations. The original design of the treaties aimed at deactivating any kind of debt relation between Member States. Accordingly, monetary stability was guaranteed by the Bretton Woods agreement, within the framework of which Members of the Communities could adjust their exchange rate if needed. In addition, capital movements were under strict control, thus reducing the risk of balance of payments disequilibria, which even if they did occur could be addressed through multilateral loans subject to soft conditionality -tackling systemic malfunctions and therefore not imposing severe cutbacks on national economic policies.

Several events have transformed this design and created the opportunity for debt relations to gain momentum. In this respect the collapse of the Bretton Woods system was crucial. The EMS, mimicking that system, imposed stricter constraints on national economies by pegging their currencies to the Deutsche Mark. Then unilateral liberalization of capital movements by the United Kingdom unleashed a new dynamic according to which all Member States were forced to do the same. When EMU was agreed and the common currency created, Member States renounced their exchange rate and the ability to create money through their central banks, thus severing their toolkit for facing imbalances and even economic crises. Simultaneously, foreign capital (especially intra-EMU, which avoided the risk associated with currency fluctuations) flooded peripheral economies and created a breeding ground for massive economic imbalances that radically turned into a debt crisis when the financial crisis reached European states and required transformation of private into public debt. The subsequent regime has adapted to these requirements and thus for the first time recognises state-to-state debt within European integration.

The gradual evolution of debt relations between Member States explains how the power relations of which they are the source became more pronounced in the course of integration and ultimately resulted in radical tensions between creditor and debtor states (thus nourishing the sovereign rather than the integrated side of Member States ${ }^{63}$ ) and led in the end to their institutionalisation (and thus to transcending the principle of equality between states). Actual, direct and concrete debt relations between Eurozone Member States

62 T. Beukers, 'The New ECB and its Relationship with the Eurozone Member States: Between Central Bank Independence and Central Bank Intervention', (2013) 50 Common Market Law Review, 1579-1620.

63 For some authors both are the two sides of the same coin (see the 'constitutional synthesis theory' in J. E. Fossum and A. J. Menéndez, The Constitution's Gift: A Constitutional Theory for a Democratic European Union, Rowman \& Littlefield, Lanham, 2011). After all, it seems that, depending on external factors, one side is more likely than the other to be on top after flipping that coin. 
are incompatible with the regulatory ideal of a union of equals. Consequently, European integration has been adapted to the new reality of debt relations. This is particularly evident in the role played by the Council in the institutional system: originally it was the central institution of the Communities, safeguarding equality between all Member States, but when after the Maastricht Treaty (and especially after the crisis) it gradually regained a dominant position, ${ }^{64}$ this time it did so reflecting power relations. Not only have decision-making processes been refashioned, locking in the power of creditors; less obviously but more pervasively, institutions have tended to internalise the interests of creditors. This is clearly evident in the role played by institutions monitoring the now strict conditionality of financial assistance. Indeed, creditor power is in the process of being entrenched in European and national law. This is at work in the ruling of the German Constitutional Court upholding the ESM Treaty provisions that de facto protect the right of the Bundestag to decide how to spend taxpayer's money, but that simultaneously does not guarantee other national parliaments the same power. ${ }^{65}$ This entails that the German Constitutional Court is happy with a rule that has deeply asymmetric effects, and that makes the Union to which Germany belongs a union based on inequality (something that the Karlsruhe judges would be forced to reject were Germany a smaller and/or less economically powerful country). ${ }^{66}$ Double standards result from the peculiar legalisation of economic conflict dynamics. The renunciation of constitutional pluralism, illustrated by debates about expulsions from the EU, is but the other side of the coin.

64 Puetter, n. 39.

65 See Article 4.4 ESM Treaty and discussion above.

66 German Federal Constitutional Court, Judgment of the Second Senate of 12 September 2012 - 2 BvR $1390 / 12$ paras. (1-319), DE:BVerfG:2012:rs20120912.2bvr139012. 